\title{
PROSES BERPIKIR MAHASISWA PENDIDIKAN MATEMATIKA DALAM PEMECAHAN MASALAH PEMBUKTIAN TAHUN AKADEMIK 2014/2015
}

\author{
Dian Devita Yohanie ${ }^{1}$, Imam Sujadi ${ }^{2}$, Budi Usodo ${ }^{3}$ \\ ${ }^{1,2,3}$ Prodi Magister Pendidikan Matematika, FKIP Universitas Sebelas Maret Surakarta
}

\begin{abstract}
This research aimed to describe the thinking process in proof problem solving using direct, contraposition, and contradiction methods in $2^{\text {nd }}$ semester mathematic education students of Nusantara PGRI University of Kediri with (1) high, (2) moderate, and (3) low learning achievements. The research method employed was qualitative approach. Subject of research was selected using purposive sampling technique, consisting of $62^{\text {nd }}$-semester mathematic education students: 2 students with high, 2 with moderate, and 2 with low learning achievements. Data collection was carried out using interview based on proof problem solving assignment. Data validation was carried out using time triangulation, and the valid data was analyzed using data reduction, data display, and conclusion drawing. The result of research showed that: (1) The thinking process of students with high learning achievement. The proof problem solving in direct contraposition, and contradiction ways. In entry phase, the subjects understood the problem by writing antecedent as they know and consequence to be proved. In finishing phase, the subjects explained antecedent into premise correctly and completely, did algebraic operation to connect consequence to premise, in order to prove the consequence. In review phase, the subjects check their answer and were sure with their answer after seeing the process and proof result. (2) The thinking process of students with moderate learning achievement. The proof problem solving in direct, contraposition, and contradiction ways. In entry phase, the subjects understood the problem by writing antecedent as they know and consequence to be proved. In finishing phase, the subjects explained antecedent into premise correctly, did algebraic operation with summing procedure and distributive property to connect consequence to premise in order to prove the consequence. In review phase, the subjects did not check their answer and were sure with their answer when their proved. (3) The thinking process of students with low learning achievement. The proof problem solving in direct, contraposition, and contradiction ways. In entry phase is the same, the subjects understood the problem by writing antecedent as they know and consequence to be proved. In finishing phase, the subjects explained antecedent into premise difficultly, did algebraic operation with summing procedure and distributive property to connect consequence to premise using number example, thereby could not prove the consequence. Then in review phase, the subjects did not check their answer and were sure with their answer after seeing their proof result.
\end{abstract}

Keywords: Thinking Process, Problem Solving, Proof, Learning Achievement

\section{PENDAHULUAN}

Masalah adalah suatu situasi yang mendorong seseorang untuk menyelesaikannya tetapi tidak tahu secara langsung apa yang harus dikerjakan untuk menyelesaikannya. Apabila seseorang mempunyai suatu permasalahan tetapi belum dapat menyelesaikannya maka situasi tersebut merupakan suatu masalah. Menurut Ruseffendi (dalam Minarni, 2012:93) masalah merupakan suatu persoalan yang tidak dikenalnya dan orang tersebut berkeinginan dan berkemampuan untuk menyelesaikannya, terlepas apakah ia dapat mengerjakannya dengan benar atau tidak. Seseorang yang menganggap suatu soal bukan merupakan masalah yaitu apabila orang tersebut telah mengetahui cara atau proses untuk mendapatkan pemecahannya. 
Pemecahan masalah merupakan proses menemukan kombinasi aturan-aturan yang telah dipelajari lebih dahulu yang digunakan untuk memecahkan masalah yang baru Nasution (2011:170). Menurut National Council of Supervisors of Mathematics (NCSM) (dalam Minarni, 2012:94) pemecahan masalah merupakan "The process of applying knowlegde to an unknown and unfamiliar situations." Kalimat tersebut bermakna pemecahan masalah merupakan suatu proses dalam menerapkan pengetahuan ke dalam situasi yang tidak diketahui dan dikenal. Pemecahan masalah dalam penelitian ini adalah pemecahan masalah pembuktian (problem to prove).

Bukti adalah suatu argumentasi logis untuk memberikan suatu kepastian tentang kebenarannya. Pembuktian menurut Susanto (2011a:191) merupakan sekumpulan argumen logis untuk menunjukkan kebenaran suatu pernyataan. Selanjutnya menurut O'Daffer dan Thornquist (dalam NCTM, 1993:49) "Mathematical proving is a process that uses definition, postulates, previously proven statements, and deductive reasoning to produce a sequence of true statement providing a valid argument that a statement to be proved is true." Kalimat tersebut bermakna pembuktian matematika merupakan proses yang menggunakan definisi, postulat, pernyataan yang telah terbukti sebelumnya, dan penalaran deduktif untuk menghasilkan serangkaian pernyataan yang benar menjadi argumen yang valid bahwa pernyataan yang harus dibuktikan benar.

Berpikir didefinisikan sebagai suatu proses. Sejalan dengan pendapat Mujtaba dan Kennedy (2005:229) berpikir merupakan suatu proses seperti berikut "Thinking the process of formulating, concisely understanding, reasening, or reflecting in one's mind." Kalimat tersebut bermakna berpikir merupakan proses untuk merumuskan, memahami secara singkat, mempertimbangkan, atau membayangkan dalam satu pemikiran.Leng dan Hoo (1997:118) mengungkapkan bahwa berpikir adalah "Mental activities of examining to make sense out of experience regardless of specific content". Kalimat tersebut bermakna aktivitas mental mengkaji untuk memahami pengalaman terlepas dari konten tertentu.

Proses berpikir merupakan proses atau jalannya berpikir. Menurut Suryabrata (2012:55) proses atau jalannya berpikir itu pokoknya ada tiga langkah, yaitu pembentukan pengertian, pembentukan pendapat dan penarikan kesimpulan. Selanjutnya menurut Mason, et al (2010:24) proses berpikir matematis dalam menyelesaikan pertanyaan dibagi menjadi tiga fase yang disebut fase masuk(entry phase), menyelesaikan (attack phase), dan meninjau ulang (review phase)sebagai berikut: (a) Fase masuk (entry phase). Fase masuk dimulai ketika pertama kali bertemu dengan pertanyaan. Fase masuk dilakukan untuk mengatasi suatu pertanyaan yaitu dimulai ketika pertama kali menghadapi pertanyaan dan berakhir ketika telah memulai untuk mencoba 
memecahkannya. (b) Fase menyelesaikan (attack phase). Fase menyelesaikan seharusnya menjadi bagian yang paling penting karena mencakup bagian terbesar dari aktivitas matematika yang dilakukan. Fase menyelesaikan dapat dikatakan lengkap jika masalah ditinggalkan atau diselesaikan. Fase menyelesaikan dilakukan dengan cara mengambil beberapa pendekatan yang dapat digunakan serta merumuskan dan mencoba rencana. Apabila rencana telah dilakukan, maka akan dapat kemajuan yang baik dalam bekerja untuk menyelesaikan masalah. (c) Fase meninjau ulang (review phase). Fase review dilakukan ketika telah mencapai solusi cukup memuaskan atau ketika akan menyerah, sehingga penting untuk meninjau pekerjaan yang telah dilakukan.Fase review berguna dalam merefleksi dari fase-fase sebelumnya. Pada fase ini akan membantu untuk memeriksa apakah proses berpikir matematika dalam pemecahan masalah sudah benar dan apakah masalah telah dapat diselesaikan. Aktivitas pada fase review adalah cara penyelesaian masalah dan refleksi mengenai hal yang telah dilakukan dan mengapa melakukan hal tersebut.

Dalam memecahkan suatu masalah pembuktian kemungkinan setiap mahasiswa mempunyai proses yang berbeda-beda, karena proses berpikir dan analisis setiap mahasiswa berbeda. Sesuai dengan pendapat Santos, et al (2010:601) yang bermakna, individu yang berbeda akan menghasilkan pendekatan atau proses yang berbeda untuk memecahkan tugas atau masalah. Siswono (2002:45) mengungkapkan kemampuan berpikir seseorang dipengaruhi intelegensinya, sehingga ada kaitan antara intelegensi dengan proses belajar matematika. Menurut Orton (dalam Chairani, 2015: 16) analisis dari berbagai penelitian tentang kemampuan manusia menunjukkan berbagai variasi dan perbedaan. Salah satu hasil penelitian mengindikasikan bahwa kapasitas intelektual umumnya merupakan sesuatu yang dominan mempengaruhi kemampuan matematika, dan ini yang merupakan alasan seseorang memiliki kemampuan matematika melebihi yang lain, dan hal ini merupakan hal penting untuk mempertimbangkan perbedaan individual. Dari pendapat tersebut maka peneliti ingin mengetahui proses berpikir mahasiswa yang berprestasi belajar tinggi, sedang, dan rendah

Tujuan penelitian ini adalah untuk mendeskripsikan: (1) proses berpikir mahasiswa pendidikan matematika semester 2 yang berprestasi belajar tinggi dalam pemecahan masalah pembuktian secara langsung, kontraposisi, dan kontradiksi, (2) proses berpikir mahasiswa pendidikan matematika semester 2 yang berprestasi belajar sedang dalam pemecahan masalah pembuktian secara langsung, kontraposisi, dan kontradiksi, (3) proses berpikir mahasiswa pendidikan matematika semester 2 yang berprestasi belajar rendah dalam pemecahan masalah pembuktian secara langsung, kontraposisi, dan kontradiksi. 


\section{METODE PENELITIAN}

Penelitian ini termasuk dalam jenis penelitian dengan pendekatan kualitatif. Penelitian dilaksanakan di Universitas Nusantara PGRI Kediri pada mahasiswa program studi pendidikan matematika semester 2 Tahun Akademik 2014/2015. Subjek penelitian dipilih secara purposive sampling yaitu 6 mahasiswa pendidikan matematika semester 2 dengan subjek masing-masing terdiri dari dua mahasiswa berprestasi belajar tinggi, sedang, dan rendah.

Instrumen penelitian yang digunakan yaitu peneliti sebagai instrumen utama, lembar tugas pemecahan masalah pembuktian sebagai instrumen bantu pertama dan pedoman wawancara sebagai instrumen bantu kedua. Teknik pengumpulan data dalam penelitian ini dilakukan dengan menggunakan metode wawancara berbasis tugas yang dilakukan oleh peneliti sendiri sebagai instrumen utama kepada setiap subjek. Sebelum dilakukan wawancara, terlebih dahulu kepada setiap sujek diberikan tugas pemecahan masalah pembuktian.

Untuk memeriksa keabsahan data yang diperoleh maka digunakan uji kredibilitas data dengan cara triangulasi. Triangulasi yang digunakan dalam penelitian ini adalah triangulasi waktu. Dalam penelitian ini analisis data yang dilakukan melalui reduksi data, penyajian data, dan penarikan kesimpulan.

\section{HASIL PENELITIAN DAN PEMBAHASAN}

Berdasarkan hasil triangulasi dari data penelitian, dapat diperoleh bahwa:

1. Proses berpikir mahasiswa yang berprestasi belajar tinggi.

a. Proses berpikir mahasiswa pada subjek AA dan subjek MY pada pemecahan masalah pembuktian secara langsung.Adapun kesamaan subjek AA dan subjek MY dalam pemecahan masalah pembuktian secara langsung sebagai berikut. Pada fase masuk, kedua subjek dapat memahami masalah yang diberikan. Subjek menuliskan apa yang diketahui dari soal dengan benar yaitu informasi pada soal dan anteseden. Selanjutnya subjek menuliskan apa yang harus dibuktikan dari soal dengan benar yaitu konsekuen. Pada fase menyelesaikan kedua subjek menyelesaikan pembuktian jumlah dua bilangan ganjil adalah bilangan genap dengan benar. Selanjutnya subjek melakukan operasi perhitungan dengan langkah menjumlahkan dua bilangan dan melakukan sifat distributif untuk mengaitkan antara konsekuen dengan premis. Subjek dapat menyelesaikan proses pembuktian dengan benar dan sistematis baik dari segi aljabar maupun syarat dari bilangan genap. Subjek juga menunjukkan konsekuen dengan benar dan lengkap dengan syarat yang memenuhi. Pada fase review kedua subjek memeriksa proses 
pembuktiannya dan meyakini bahwa penyelesaiannya telah dapat membuktikan dari masalah yang telah dibuktikan.Perbedaan pada subjek AA dalam menuliskan pemisalan dua bilangan ganjil dianggap sama, sedangkan subjek MY menuliskan pemisalan untuk dua bilangan ganjil berbeda. Perbedaan proses berpikir yang terjadi berupa perbedaan dalam menyatakan masalah. Hal ini sependapat dengan Montague (dalam Zhu, 2007:188) yang bermakna, dalam memecahkan masalah ada dua langkah yaitu menyatakan masalah dan menyelesaikan masalah. Keduanya dianggap mewakili masalah sebagai dasar untuk memahami masalah dan membuat rencana untuk memecahkan masalah. Dari pendapat tersebut, maka kegiatan atau proses menyusun dan menerapkan rencana berdasarkan pengetahuan yang diperoleh dari masing-masing subjek untuk menyelesaikan suatu masalah.

b. Proses berpikir dalam pemecahan masalah pembuktian tidak langsung secara kontraposisi.Adapun kesamaan subjek AA dan subjek MY dalam pemecahan masalah pembuktian tidak langsung secara kontraposisi sebagai berikut. Pada fase awal kedua subjek memahami masalah yang diberikan. Subjek juga menuliskan apa yang diketahui dari soal yaitu informasi yang ada pada soal. Selanjutnya subjek menuliskan apa yang harus dibuktikan dari soal yaitu pernyataan implikasi yang akan dibuktikan. Setelah itu subjek membentuk pernyataan kontraposisi yang akan dibuktikan dengan benar yaitu dengan cara mengkontraposisikan pernyataan implikasi yang diketahui. Pada fase menyelesaikan kedua subjek mengaitkan konsekuen dengan premis yang telah diperoleh dengan menggunakan operasi perhitungan dan sifat bilangan sehingga membentuk proses pembuktian. Proses pembuktian yang dilakukan subjek jelas dan sistematis yaitu subjek dapat memisalkan anteseden dan konsekuen dengan benar. Subjek dapat menentukan negasi dari pernyataan anteseden dan konsekuen. Subjek juga dapat menuliskan pernyataan tersebut dalam bentuk kontraposisi dengan benar. Subjek dapat menyelesaikan pernyataan tersebut dalam bentuk aljabar. Selanjutnya dapat menarik kesimpulan akan kebenaran pernyataan sebagai akibat ekuivalensi dari pernyataan kontraposisi dengan benar. Pada fase review kedua subjek memeriksa kembali penyelesaiannya dan subjek merasa yakin bahwa penyelesaiannya telah dapat membuktikan dari masalah yang telah dibuktikan. Sedangkan pada subjek AA dan MY tidak memiliki perbedaan dalam menyelesaikan masalah pembuktian tak langsung dengan cara kontraposisi. 
c. Proses berpikir dalam pemecahan masalah pembuktian tidak langsung secara kontradiksi.Adapun kesamaan yang dimiliki oleh subjek AA dan MY pada pemecahan masalah pembuktian tidak langsung secara kontradiksi sebagai berikut. Pada fase awal kedua subjek dapat memahami cara yang akan dibuktikan dengan bukti kontradiksi dan subjek juga dapat menentukan yang akan dibuktikan yaitu kontradiksi (ingkaran) bernilai salah. Pada fase menyelesaikan kedua subjek dapat membentuk pernyataan tersebut dalam bentuk pernyataan implikasi. Subjek dapat menentukan ingkaran dari pernyataan berimplikasi. Subjek dapat membentuk pernyataan dengan konjungsi yang bersifat komutatif. Subjek dapat menyelesaikan pernyataan tersebut dalam bentuk aljabar. Subjek dapat menentukan hasil ingkarannya salah. Selanjutnya subjek dapat menarik kesimpulan kebenaran pernyataan yaitu kontradiksinya bernilai salah. Pada fase review kedua subjek memeriksa kembali penyelesaiannya dan subjek merasa yakin bahwa penyelesaiannya telah dapat membuktikan dari masalah yang telah dibuktikan. Sedangkan subjek AA dan MY tidak memiliki perbedaan dalam menyelesaikan masalah pembuktian tidak langsung dengan cara kontradiksi.

2. Proses berpikir mahasiswa yang berprestasi belajar sedang.

a. Proses berpikir mahasiswa pada subjek PAD dan subjek EF pada pemecahan masalah pembuktian secara langsung.Adapun kesamaan subjek PAD dan subjek EF dalam pemecahan masalah pembuktian secara langsung sebagai berikut. Pada fase awal proses berpikir yang dilakukan kedua subjek adalah memahami soal dengan menuliskan yang diketahui dari soal dan menuliskan apa yang harus dibuktikan dari soal dengan benar yaitu konsekuen. Pada fase menyelesaikan proses berpikir yang dilakukan kedua subjek adalah subjek menyelesaikan pembuktian jumlah dua bilangan ganjil adalah bilangan genap dengan benar. Selanjutnya subjek melakukan operasi perhitungan dengan langkah menjumlahkan dua bilangan dan melakukan sifat distributif untuk mengaitkan antara konsekuen dengan premis. Subjek dapat menyelesaikan proses pembuktian dengan benar dan sistematis baik dari segi aljabar maupun syarat dari bilangan genap. Subjek juga menunjukkan konsekuen dengan benar dan lengkap dengan syarat yang memenuhi. Pada fase review kedua subjek tidak memeriksa jawaban yang telah dilakukan. Selanjutnya subjek merasa yakin bahwa penyelesaiannya telah dapat membuktikan dari masalah yang telah dibuktikan. Perbedaan dari dua subjek tersebut terdapat pada fase menyelesaikan untuk subjek PAD menjelaskan dan menyelesaikan dengan benar dengan hanya satu kali penjelasan, sedangkan pada subjek EF menjelaskan dan menyelesaikan langkah-langkah pembuktian 
dengan berulang kali penjelasan hingga sampai ke penyelesaian kebenaran pembuktian. Hal ini didukung oleh pendapat Hanna (dalam Imamoglu dan Togrol, 2010:79) yang bermakna, pembuktian matematika dianggap sebagai argumentasi yang diperlukan untuk mengesahkan suatu pernyataan, argumentasi yang mungkin mengambil beberapa bentuk atau cara yang berbeda asalkan meyakinkan. Dari pendapat tersebut, maka proses pembuktian yang dilakukan kedua subjek tersebut mempunyai cara yang berbeda untuk menyelesaikan kebenaran pembuktian.

b. Proses berpikir dalam pemecahan masalah pembuktian tidak langsung secara kontraposisi.Adapun kesamaan subjek PAD dan subjek EF dalam pemecahan masalah pembuktian tidak langsung secara kontraposisi sebagai berikut. Pada fase masuk kedua subjek memahami masalah yang diberikan. Subjek menuliskan apa yang diketahui dari soal yaitu informasi yang ada pada soal. Selanjutnya subjek menuliskan apa yang harus dibuktikan dari soal yaitu pernyataan implikasi yang akan dibuktikan. Setelah itu subjek membentuk pernyataan kontraposisi yang akan dibuktikan dengan benar yaitu dengan cara mengkontraposisikan pernyataan implikasi yang diketahui. Pada fase menyelesaikan proses berpikir yang dilakukan adalah subjek menjabarkan anteseden menjadi premis yang terkait dengan jelas. Selanjutnya subjek mengaitkan konsekuen dengan premis yang telah diperoleh dengan menggunakan operasi perhitungan dan sifat bilangan sehingga membentuk proses pembuktian. Proses pembuktian yang dilakukan subjek jelas dan sistematis yaitu subjek dapat memisalkan anteseden dan konsekuen dengan benar. Subjek dapat menentukan negasi dari pernyataan anteseden dan konsekuen. Subjek juga dapat menuliskan pernyataan tersebut dalam bentuk kontraposisi dengan benar. Subjek dapat menyelesaikan pernyataan tersebut dalam bentuk aljabar. Selanjutnya dapat menarik kesimpulan akan kebenaran pernyataan sebagai akibat ekuivalensi dari pernyataan kontraposisi dengan benar. Pada fase review kedua subjek tidak memeriksa kembali penyelesaiannya dan subjek merasa yakin bahwa penyelesaiannya telah dapat membuktikan dari masalah yang telah dibuktikan. Pada subjek PAD dan EF tidak terdapat perbedaan dalam menyelesaikan masalah pembuktian tidak langsung secara kontraposisi.

c. Proses berpikir dalam pemecahan masalah pembuktian tidak langsung secara kontradiksi. Adapun kesamaan proses berpikir pada subjek PAD dan subjek EF sebagai berikut. Pada fase masuk yang dilakukan kedua subjek adalah subjek dapat menuliskan soal dengan benar. Subjek dapat memahami cara yang akan 
dibuktikan dengan bukti kontradiksi dan subjek juga dapat menentukan yang akan dibuktikan yaitu kontradiksi (ingkaran) bernilai salah. Fase menyelesaikan bahwa subjek dapat membentuk pernyataan tersebut dalam bentuk pernyataan implikasi. Subjek dapat menentukan ingkaran dari pernyataan berimplikasi. Subjek dapat membentuk pernyataan dengan konjungsi yang bersifat komutatif. Subjek dapat menyelesaikan pernyataan tersebut dalam bentuk aljabar. Subjek dapat menentukan hasil ingkarannya salah. Selanjutnya subjek dapat menarik kesimpulan kebenaran pernyataan yaitu kontradiksinya bernilai salah. Pada fase review, proses berpikir yang dilakukan kedua subjek adalah subjek tidak memeriksa kembali penyelesaiannya dan subjek merasa yakin bahwa penyelesaiannya telah dapat membuktikan dari masalah yang telah dibuktikan. Sedangkan pada subjek PAD dan EF tidak terdapat perbedaan dalam menyelesaikan masalah pembuktian tidak langsung secara kontraposisi. Sedangkan perbedaan proses berpikir masing-masing subjek terdapat pada fase menyelesaikan untuk subjek PAD menjelaskan dan menyelesaikan dengan benar dengan hanya satu kali penjelasan, sedangkan pada subjek MY menjelaskan dan menyelesaikan langkah-langkah pembuktian dengan berulang kali penjelasan hingga sampai ke penyelesaian kebenaran pembuktian.Hal ini didukung oleh Hanna (dalam Imamoglu dan Togrol, 2010:79) yang bermakna, pembuktian matematis dianggap sebagai argumentasi yang diperlukan untuk mengesahkan suatu pernyataan, argumentasi yang mungkin mengambil cara yang berbeda asalkan meyakinkan. Dari pendapat tersebut, maka proses pembuktian yang dilakukan kedua subjek tersebut mempunyai cara yang berbeda untuk menyelesaikan kebenaran pembuktian.

3. Proses berpikir mahasiswa yang berprestasi belajar rendah.

a. Proses berpikir pada mahasiswa pada subjek YNK dan DW dalam pemecahan masalah pembuktian secara langsung. Adapun kesamaan proses berpikir pada subjek YNK dan subjek DW sebagai berikut. Pada fase masuk kedua subjek dapat memahami soal yaitu dengan menuliskan soal jumlah dua bilangan ganjil adalah bilangan genap, dan kedua subjek memahami mengenai apa yang akan dibuktikan. Fase menyelesaikan kedua subjek kurang memahami dalam memisalkan anteseden. Sehingga subjek tidak benar dalam menunjukkan konsekuen. Selanjutnya subjek juga kurang memahami pernyataan yang harus dibuktikan. Fase review kedua subjek tidak memeriksa kembali proses pembuktian dan subjek yakin dengan jawabannya. 
b. Proses berpikir untuk pemecahan masalah pembuktian tidak langsung dengan cara kontraposisi.Adapun kesamaan proses berpikir pada subjek YNK dan subjek DW adalah sebagai berikut. Pada fase masuk subjek dapat menuliskan soal dengan benar dan subjek dapat memahami pernyataan kontraposisi yang akan dibuktikan. Pada fase menyelesaikan subjek tidak konsisten dalam pemisalan pernyataan yang dituliskan. Walaupun penarikan kesimpulannya benar namun proses pembuktiannya tidak benar. Fase review subjek tidak memeriksa kembali proses pembuktian dan subjek yakin dengan jawabannya.

c. Proses berpikir untuk pemecahan masalah pembuktian tidak langsung dengan cara kontradiksi. Adapun kesamaan subjek YNK dan DW pada fase awal subjek menuliskan soal dengan benar dan subjek kurang memahami soal yang akan dibuktikan karena subjek tidak membentuk pernyataan kontradiksi yang akan dibuktikan. Fase menyelesaikan subjek tidak benar dalam menuliskan secara aljabar. Subjek dapat membuat kesimpulan kontradiksinya bernilai salah, tetapi belum dapat menjelaskan pernyataan itu bernilai benar. Subjek tidak dapat membuktikan konsekuen karena proses pembuktian yang dilakukan tidak benar. Fase review subjek tidak memeriksa kembali proses pembuktian dan subjek yakin dengan jawabannya. Perbedaan proses berpikir pemecahan masalah pembuktian tak langsung secara kontradiksi yang terdapat padafase penyelesaian terhadap subjek YNK adalah subjek tidak dapat memisalkan bilangan yang tidak habis dibagi 3, sedangkan subjek DW dapat memisalkan bilangan yang tidak habis dibagi 3.

\section{SIMPULAN DAN SARAN}

Berdasarkan hasil penelitian yang telah diuraikan, penelitian ini menghasilkan deskripsi proses berpikir mahasiswa dalam pemecahan masalah pembuktian pada masingmasing tingkat prestasi belajar mahasiswa sebagai berikut: (1) Proses berpikir mahasiswa yang berprestasi belajar tinggi dalam pemecahan masalah pembuktian dengan cara langsung, kontraposisi, dan kontradiksi pada fase masuk aktivitas proses berpikir yang diperolehsama, yaitu subjek memahami masalah dengan menuliskan anteseden sebagai yang diketahui dan konsekuen sebagai yang harus dibuktikan. Fase penyelesaian, subjek benar dan lengkap dalam menjabarkan anteseden menjadi premis, melakukan operasi perhitungan dengan langkah penjumlahan dan sifat distributif untuk mengaitkan konsekuen dengan premis, benar dan jelas dalam membuktikan konsekuen. Sedangkan pemecahan masalah pembuktian tak langsung cara kontraposisi dan kontradiksi pada fase penyelesaian, subjek benar dan lengkap dalam menjabarkan antesen menjadi premis, 
melakukan operasi perhitungan dengan langkah pengkuadratan dan sifat distributif untuk mengaitkan konsekuen dengan premis, benar dalam membuktikan konsekuen. Selanjutnya pada fase review untuk pemecahan masalah pembuktian dengan cara langsung, kontraposisi, dan kontradiksi, subjek memeriksa jawaban dan yakin dengan jawabannya setelah melihat proses dan hasil pembuktian. (2) Proses berpikir mahasiswa yang berprestasi belajar sedang dalam pemecahan masalah pembuktian dengan cara langsung, kontraposisi, dan kontradiksi pada fase masuk aktivitas proses berpikir yang yang diperoleh sama, yaitu subjek memahami masalah dengan menuliskan anteseden sebagai yang diketahui dan konsekuen sebagai yang harus dibuktikan. Fase penyelesaian, subjek benar dalam menjabarkan anteseden menjadi premis, melakukan operasi perhitungan dengan langkah penjumlahan dan sifat distributif untuk mengaitkan konsekuen dengan premis, benar dalam membuktikan konsekuen. Sedangkan pemecahan masalah pembuktian tak langsung cara kontraposisi dan kontradiksi pada fase penyelesaian, subjek benar dalam menjabarkan antesen menjadi premis, melakukan operasi perhitungan dengan langkah pengkuadratan dan sifat distributif untuk mengaitkan konsekuen dengan premis, benar dalam membuktikan konsekuen. Selanjutnya pada fase review untuk pemecahan masalah pembuktian dengan cara langsung, kontraposisi, dan kontradiksi, subjek tidak memeriksa jawaban dan yakin dengan jawabannya saat pembuktiannya terbukti. (3) Proses berpikir mahasiswa yang berprestasi belajar rendah dalam pemecahan masalah pembuktian dengan cara langsung, kontraposisi, dan kontradiksi pada fase masuk aktivitas proses berpikir yang diperolehsama, yaitu, subjek memahami masalah dengan menuliskan anteseden sebagai yang diketahui dan konsekuen sebagai yang harus dibuktikan. Fase penyelesaian, subjek mengalami kesulitan dalam menjabarkan anteseden menjadi premis, melakukan operasi perhitungan dengan langkah penjumlahan dan sifat distributif untuk mengaitkan konsekuen dengan premis dengan menggunakan contoh bilangan, subjek membuktikan konsekuen dengan membentuk bilangan agar memenuhi konsekuen. Sedangkan pemecahan masalah pembuktian tak langsung cara kontraposisi dan kontradiksi pada fase penyelesaian, subjek benar dalam menjabarkan antesen menjadi premis, melakukan operasi perhitungan dengan langkah pengkuadratan dan sifat distributif untuk mengaitkan konsekuen dengan premis, subjek membuktikan konsekuen namun tidak benar proses pembuktiannya. Selanjutnya pada fase review untuk pemecahan masalah pembuktian dengan cara langsung, subjek tidak memeriksa jawaban dan yakin dengan jawabannya setelah melihat contoh-contoh bilangan. Sedangkan untuk pemecahan masalah pembuktian tak langsung cara kontraposisi, dan kontradiksi, subjek tidak memeriksa jawaban dan yakin dengan jawabannya dengan melihat hasil pembuktiannya. 
Saran hasil penelitian ini adalah sebagai berikut. (1) Bagi mahasiswa, dalam membuktikan pemecahan masalah pembuktian hendaknya perlu meninjau ulang kembali proses pembuktian yang telah dikerjakan. (2) Bagi dosen, sebaiknya dalam pembelajaran pembuktian lebih mempertimbangkan fase-fase proses berpikir yang digunakan. (a) Fase masuk, lebih memperhatikan kejelasan kalimat pada soal agar lebih mudah dipahami oleh mahasiswa, menggunakan metode pembelajaran yang lebih efektif selain pembelajaran langsung sehingga lebih membantu mahasiswa yang berprestasi belajar rendah dalam memahami materi. (b) Fase penyelesaian, memberikan pemahaman mengenai pembuktian tak langsung secara kontraposisi dan kontradiksi pada mahasiswa yang berprestasi belajar rendah, melakukan pendekatan kepada mahasiswa yang berprestasi belajar rendah agar lebih teliti dalam melakukan proses pembuktian. (c) Fase review, melakukan pendekatan kepada mahasiswa yang berprestasi belajar tinggi, sedang, dan rendah agar dapat mengungkapkan kembali hasil penyelesaian untuk memeriksa kembali kelengkapan dan kebenaran dari proses pembuktian yang telah dilakukan. (3) Bagi penelitian lebih lanjut, hendaknya meninjau kembali secara mendalam hal-hal yang terkait dengan fase-fase proses berpikir mahasiswa dalam pemecahan masalah pembuktian dan menjadi bahan referensi untuk mengembangkan atau melakukan penelitian terkait pemecahan masalah pembuktian pada subjek yang memiliki karakteristik yang berbeda dengan penelitian ini.

\section{DAFTAR PUSTAKA}

Chairani, Z. 2015. Profil Metakognisi Siswa SMP Dalam Pemecahan Masalah Aljabar Berdasarkan Kemampuan Matematika. Disertasi: Universitas Negeri Surabaya.

Imamoglu, Y. dan Togrol, A. Y. 2010. Opceptualizations of the Nature and Role of Proof in School Mathematics. International Journal for Cross-Disciplinary Subjects in Educations. Volume 1, Issue 2, Pp.79-87.

Leng, Y. L. dan Hoo, C. T. 1997. "Explaining The Thinking, Learning Style, and Cognition Constructs". The Mathematics Educator. Vol. 2, No. 1, Pp.113-127.

Mason, J., Burton, L., Stacey, K. 2010. Thinking Mathematically Second Edition. England: Pearson Education Limited.

Minarni, A. 2012. Pengaruh Pembelajaran Berbasis Masalah Terhadap Kemampuan Pemecahan Masalah Matematika. Prosiding Seminar Nasional Matematika dan Pendidikan Matematika Fakultas MIPA Universitas Negeri Yogyakarta. Yogyakarta: 10 November 2012.

Mujtaba, B. G. dan Kennedy, J. W. 2005. Facilitating Trough Collaborative Reflection To Accommodate Diverse Learning Style For Long-Term Retention. Development in Business Simulations and Experiential Learning. Vol. 32, Pp. 224-232. 
Nasution, S. 2011. Berbagai Pendekatan dalam Proses Belajar dan Mengajar. Jakarta: Bumi Aksara.

NCTM. 1993. Research Ideas for The Classroom High School Mathematics. New York: Macmillan Publishing Company. Editor: Patricia S. Wilson.

Polya, G. 1973. How to Solve It. A New Aspect of Mathematical Method. United States of America: Princeton University Press.

Santos, E., Nguyen, H., Yu, F., Li, D., dan Wilkinson, J. T. 2010. "Impact of Analysis' Cognitive Style on the Analytic Process". Proceedings of 2010 IEEE/WIC/ACM International Conference on Web Intelligence and Intelligent Agent Technology.

Siswono, T. Y. E. 2002. "Proses Berpikir Siswa dalam Pengajuan Soal". Jurnal Nasional "Matematika atau Pembelajarannya". Tahun VIII, Pp. 44-50. ISSN: 0852-7792.

Sugiyono. 2011. Metode Penelitian Pendidikan Pendekatan Kuantitatif, Kualitatif, dan $R \& D$. Bandung: Alfabeta.

Suryabrata, S. 2012. Psikologi Pendidikan. Jakarta: Raja Grafindo Persada.

Susanto, H. A. 2011a. Pemahaman Pemecahan Masalah Pembuktian Sebagai Sarana Berpikir Kreatif. Prosiding Seminar Nasional Penelitian Pendidikan dan Penerapan MIPA Fakultas MIPA Universitas Negeri Yogyakarta. Yogyakarta: 14 Mei 2011.

Syahid, A. 2009. Pedoman Penulisan Tesis UNS. Surakarta: Sebelas Maret University Press.

Zhu, Z. 2007. Gender Differences in Mathematical Problem Solving Pattern: A Review of Literature. International Education Journal. Vol. 8, No. 2, Pp. 187-203. ISSN: $1443-1475$. 